Contributions:

A Study design/planning

B Data collection/entry

C Data analysis/statistics

D Data interpretation

E Preparation of manuscript

$F$ Literature analysis/search

$G$ Funds collection

\title{
ASYMMETRICAL HEARING LOSS AND MEGA CISTERNA MAGNA: A CASE STUDY
}

Ahmad A. Alanazi ${ }^{A B C D E F}$

King Saud bin Abdulaziz University for Health Sciences, Riyadh, Saudi Arabia

Address for correspondence: Ahmad A. Alanazi, College of Applied Medical Sciences, King Saud bin Abdulaziz University for Health Sciences, Riyadh, Saudi Arabia. Email: alanaziahm@ksau-hs.edu.sa

\begin{abstract}
Background: There is an unknown relationship between hearing loss, vestibular disorders, and mega cisterna magna. The purpose of this case report is to describe, for the first time, hearing and vestibular examinations and rehabilitation for an older adult with mega cisterna magna.

Case Report: This study presents the case of a 54-year-old male who complained of being hard of hearing (bilaterally), tinnitus, and dizzy spells. He had a history of working in noisy environments but no familial history of hearing loss. Several audiological and vestibular tests and magnetic resonance imaging (MRI) were administered. The subject was counseled about hearing aids and fitted with a 'bilateral contralateral routing of signal' (BiCROS) amplification system to overcome his hearing difficulties.

Conclusions: Mega cisterna magna can be either silent and cause no symptoms, or produce symptoms such as hearing loss, tinnitus, and dizziness. Aging and noise exposure are major causes of hearing loss and tinnitus. Further research is needed to determine the audiological and vestibular symptoms of a larger sample of patients with mega cisterna magna.
\end{abstract}

Keywords: Asymmetrical hearing loss • cisterna magna $\bullet$ dizziness $\bullet$ hearing aids $\bullet$ tinnitus

\section{PÉRDIDA DE AUDICIÓN ASIMÉTRICA Y MEGA CISTERNA MAGNA: ESTUDIO DE UN CASO}

\section{Resumen}

Antecedentes: existe una relación desconocida entre la pérdida de audición, los trastornos vestibulares y la mega cisterna magna. El propósito de este artículo es describir, por primera vez, los exámenes auditivos y vestibulares y la rehabilitación para un adulto mayor con mega cisterna magna.

Caso clínico: este estudio presenta el caso de un varón de 54 años con quejas de problemas de audición (bilateralmente), tinnitus y mareos. Como antecedentes, destaca un ámbito laboral en entornos ruidosos, pero no un historial familiar de pérdida de audición. Se realizan varias pruebas audiológicas y vestibulares, así como una resonancia magnética (RM). Se aconsejó al sujeto el uso de prótesis auditivas y se le instaló un sistema de amplificación de tipo " Ruta de la Señal Contralateral" (BiCROS) para superar sus dificultades auditivas.

Conclusiones: la mega cisterna magna puede ser silenciosa y no causar síntomas, o producir síntomas como pérdida de la audición, tinnitus y mareos. El envejecimiento y la exposición al ruido son causas importantes de pérdida de audición y tinnitus. Se necesitan más estudios para determinar los síntomas audiológicos y vestibulares de una muestra más grande de pacientes con mega cisterna magna.

Palabras clave: pérdida de audición asimétrica • cisterna magna • mareos, prótesis auditivas • tinnitus.

\section{АСИММЕТРИЧНАЯ ТУГОУХОСТЬ И ЛОКАЛЬНОЕ УВЕЛИЧЕНИЕ СУБАРАХНОИДАЛЬНЫХ ПРОСТРАНСТВ (MEGА CISTERNA MAGNA): РАЗБОР КЛИНИЧЕСКОГО СЛУЧАЯ}

\begin{abstract}
Аннотация
Вступление: Существует неизвестная связь между потерей слуха, вестибулярными нарушениями и локальным увеличением субарахноидальных пространств (Mega Cisterna Magna). Данная работа впервые описывает результаты аудиологических и вестибулярных исследований, а также результаты реабилитации взрослого пациента с Mega Cisterna Magna.

Описание случая: Данная работа описывает историю болезни 54-летнего мужчины, который жаловался на (двустороннюю) тугоухость, тиннитус и головокружение. В анамнезе информация о том, что пациент работал в шуме, а в семье не были зарегестрированы проблемы со слухом. Были проведены аудиологические и вестибулярные исследования, а также магнитно-резонансная томография (МРТ). Пациент получил информацию о возможности использования слуховых аппаратов и системы усиления «двустороннего контралатерального сигнала» (BiCROS) для решения проблемы со слухом.

Выводы: Mega Cisterna Magna может не иметь и не вызывать никаких симптомов, а может проявляться тугоухостью, ушным шумом и головокружением. Процесс старения и воздействие шума являются основными причинами тугоухости и появления
\end{abstract}


тиннитуса. Необходимы дальнейшие исследования для определения аудиологических и вестибулярных симптомов на большей группе пациентов с Mega Cisterna Magna.

Ключевые слова: асимметричная тугоухость • локальное увеличение субарахноидальных пространств • Mеga Сisterna Magna - головокружение • слуховые аппараты • тиннитус.

\title{
ASYMETRYCZNY UBYTEK SŁUCHU I MEGA CISTERNA MAGNA: STUDIUM PRZYPADKU
}

\begin{abstract}
Streszczenie
Wstęp: Istnieje nieznany związek między ubytkiem słuchu, zaburzeniami przedsionkowymi i mega cisterna magna. Celem pracy jest opisanie po raz pierwszy wyników badań słuchu, badań przedsionkowych oraz rehabilitacji dla przypadku osoby z mega cisterna magna.

Opis przypadku: W niniejszej pracy przedstawiono przypadek 54-letniego mężczyzny, który skarżył się na (obustronny) niedosłuch, szumy uszne i zawroty głowy. Pracował w hałaśliwym otoczeniu, ale w historii rodzinnej ubytki słuchu nie występowały. Przeprowadzono kilka badań audiologicznych i przedsionkowych oraz obrazowanie metodą rezonansu magnetycznego (MRI). Pacjent został poinformowany o możliwości korzystania $\mathrm{z}$ aparatów słuchowych i zaopatrzony w system wzmacniający „dwustronnego kontrlateralnego przekierowania sygnału” (BiCROS), aby przezwyciężyć trudności w słyszeniu.
\end{abstract}

Wnioski: Mega cisterna magna może być uśpiona i nie wywoływać żadnych objawów, lub powodować takie objawy jak utrata słuchu, szumy uszne i zawroty głowy. Starzenie się i narażenie na hałas są głównymi przyczynami utraty słuchu i występowania szumów usznych. Potrzebne są dalsze badania, aby określić objawy audiologiczne i przedsionkowe u większej grupy pacjentów z mega cisterna magna.

Słowa kluczowe: asymetryczny ubytek słuchu • cisterna magna • zawroty głowy • aparaty słuchowe • szumy uszne

\section{Background}

The normal cisterna magna is a cerebrospinal fluid filled space in the brain that lies below the inferior surface of the cerebellum behind the medulla [1]. Mega cisterna magna is a benign enlarged cisterna that requires no treatment. The cisterna magna is considered dilated when its diameter is $>10 \mathrm{~mm}$, which indicates possible malformation of the central nervous system and chromosomal abnormality [2-6].

The mega cisterna magna, classified as one of the related abnormalities of Dandy-Walker complex, is the most common posterior fossa abnormality [7-9]. Other abnormalities of Dandy-Walker complex include Dandy-Walker variant and Dandy-Walker malformation. A mega cisterna magna may be associated with either infarction or infection (e.g., cytomegalovirus) or chromosomal abnormality (e.g., trisomy 18) [6-8]. However, other structures, such as the cerebellar vermis and the fourth ventricle usually remain normal. Neuroimaging [e.g., magnetic resonance imaging (MRI)] plays a major role in (a) identifying mega cisterna magna, and (b) differentiating it from other malformations, such as inferior vermian hypoplasia [7].

The prevalence and symptoms of isolated mega cisterna magna in both children and adults is not yet well established [10]. Long et al. (2006) reported that mega cisterna magna is more common in postnatal males compared to females (3.5: 1) [11]. Zimmer et al. (2007) compared the performance of memory, verbal, and fluency tasks between a group of adults with isolated mega cisterna magna and a control group, and found no significant differences in cognitive abilities between the groups. The symptoms of patients with mega cisterna magna, such as catatonia, active negativism, disrupted speech, neologisms, and severe anxiety have been described in the literature $[8,12]$. To the author's knowledge, a relationship between mega cisterna magna and hearing loss, tinnitus, and/or dizziness has not been previously reported. This case report highlights the results of hearing, vestibular, and radiological examinations in addition to the auditory rehabilitation of this unusual condition.

\section{Case description}

The subject was a 54-year-old male who complained mainly of hearing loss which had become worse over time, tinnitus commonly in the right ear, and some dizzy spells. He reported no history of pain, drainage, or ear operations, familial history of hearing loss, environmental ototoxicity, infections, trauma to the head or neck, or barotrauma. He had worked around loud noises for approximately 25 years without wearing proper ear protection. Unfortunately, he had no previous workplace (or baseline) audiograms as a benchmark when he was first seen at the clinic. His medical history included a diagnosis of skin cancer 4 years prior to the evaluation. Although he had used several medications, such as Prednison, which is used to reduce the immune system's response to disease and their symptoms, he was currently not on any medications.

Otoscopic and immittance examination, otoacoustic emissions, and pure tone and speech audiometry were done at the initial appointment. The subject was referred to an ENT physician for further investigations, including MRI, to rule out any malformations or abnormalities. In the second appointment a few weeks later, the subject returned for vestibular testing and hearing aid consultation after the MRI was complete and there was medical clearance for wearing hearing aids. After the vestibular assessments, the subject was informed of all of the options available to help improve communications. The subject was counselled that hearing aids would undoubtedly improve his communication abilities, but that they were not a cure for hearing loss and did have certain limitations. A long-term rehabilitative process would be needed in order to improve communication skills. In this way, reasonable expectations from hearing aid fitting were established. The subject was 
fitted with a bilateral contralateral routing of signal (BiCROS) amplification system in the third appointment.

Bilateral otoscopy revealed the ear canals to be free of wax and debris and the tympanic membranes were unremarkable. Tympanometry revealed a Type A tympanogram in the right ear, indicative of normal middle ear function, and a Type $A_{d}$ tympanogram in the left ear which might have resulted from ossicular discontinuity or hypermobility of a thin tympanic membrane. Ipsilateral acoustic reflex thresholds were elevated in the left ear, and were between 115-120 dB HL. Ipsilateral acoustic reflex thresholds in the right ear and contralateral acoustic reflex thresholds were absent in both ears. Distortion product otoacoustic emissions (DPOAEs) were absent in both ears, indicative of abnormal outer hair cell function.

Audiometric tests revealed asymmetrical bilateral sensorineural hearing loss (SNHL): moderate to moderately severe SNHL in the left ear and a profound SNHL in the right ear (Figure 1). Speech reception threshold (SRT) was obtained at $45 \mathrm{~dB} \mathrm{HL}$ and word recognition ability was $96 \%$ at $75 \mathrm{~dB}$ HL in the left ear. This represents good agreement between the PTA and SRT tests. No correct SRT responses were acquired in the right ear. Videonystamography (VNG) test results were normal. No abnormal findings were detected on saccades, pendular tracking, optokinetic, positional, and caloric tests. Dix Hallpike and head shake procedures were negative bilaterally. MRI showed no evidence of any mass or abnormality in the internal auditory canals or cerebellopontine angles. However, a congenitally prominent cisterna magna was found. The diameter of the cisterna magna was $>10 \mathrm{~mm}$, larger than normal.

The subject was a good candidate for a BiCROS amplification system. BiCROS is designed specifically for people who have poor hearing in one ear (i.e., no usable hearing in the ear) and an aidable hearing loss in the other. It has a signal-routing arrangement that includes one microphone that catches sounds in the ear with poor hearing and sends them to the better ear through a wired or wireless connection to the second microphone [13]. Sound is therefore amplified on both sides and put into the better ear (Figure 2). BiCROS systems can help overcome feedback because of the separation between the microphone on the poorer-hearing ear and the amplifier and receiver on the better-hearing ear. The subject was fitted with a Starkey BiCROS, and programs including normal BiCROS, restaurant BiCROS, and normal hearing aid only were added. These hearing aid settings are one of the advantages of a BiCROS system as they allow patients to decide when to stream information between the ears and when not to. The subject was satisfied with his BiCROS amplification system.

\section{Discussion}

This report adds to the literature on mega cisterna magna. Mega cisterna magna is usually an incidental finding that consists of an enlarged posterior fossa [7]. There is no reported recurrence risk [14]. Yar et al. (2012) retrospectively reviewed all post-natal Saudi cases of mega cisterna magna reported between 2007 and 2011 and found 8 out of 20 cases were abnormal and had central nervous

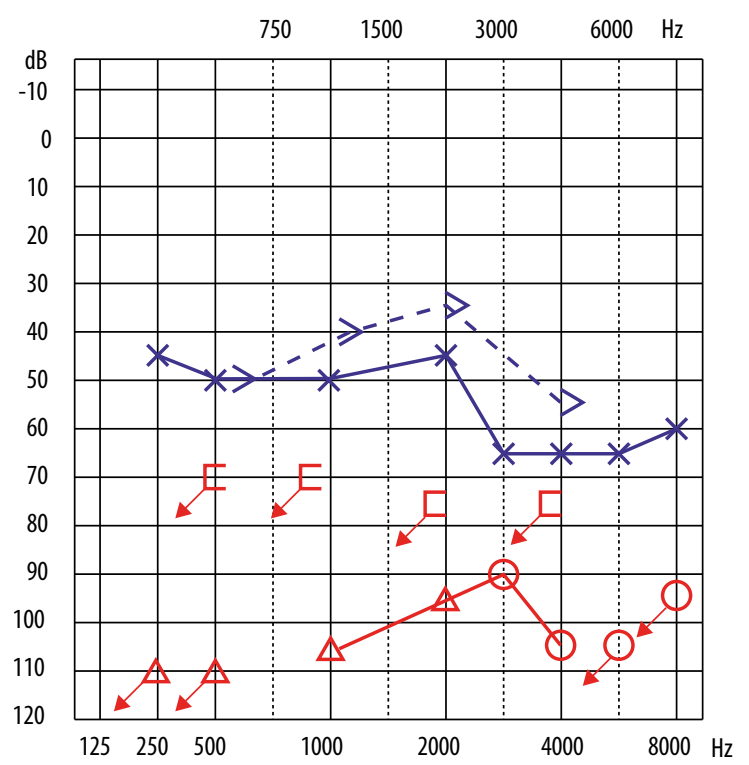

Figure 1. Audiogram using insert earphones. There was a moderate to moderately severe SNHL in the left ear and a profound $\mathrm{SNHL}$ in the right ear. $(\mathrm{X})$, air conduction for the left ear; (>), bone conduction for the left ear; (O), air conduction for the right ear; $(\Delta)$, masked air conduction for the right ear; ([), masked bone conduction for the right ear; $(\downarrow)$, no response.

system (CNS) anomalies, such as cerebellar hypoplasia [15]. They reported a high association between mega cisterna magna and CNS malformations in the Saudi population, and recommended (a) post-natal neuroimaging to confirm all abnormal fetal sonographs and (b) longterm neurocognitive assessment. The absence of such actions can mean that the early identification of mega cisterna magna among neonates at risk is missed. The current case may be one such case in which diagnosis at an early stage of life has been missed.

This case presented with asymmetrical progressive SNHL, tinnitus, and dizzy spells. It is not known how common these symptoms are in mega cisterna magna. It is therefore suggested that all children and adults who are identified

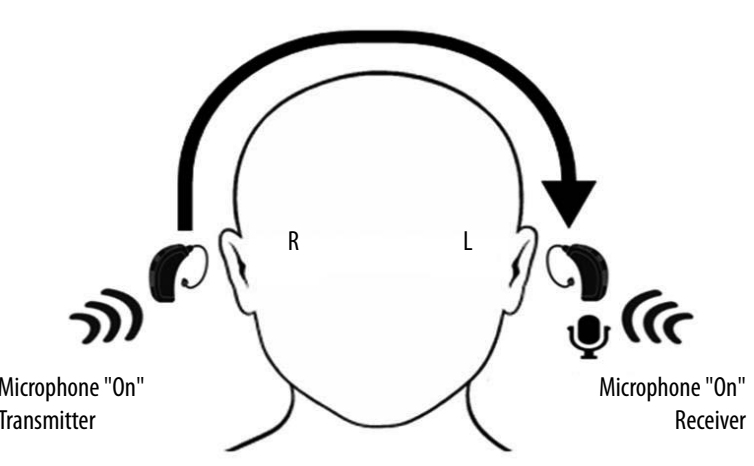

Figure 2. The BiCROS amplification system. The BiCROS microphone in the right ear transmits signals to the device in the left ear, which mixes them with its own microphone input and amplifies the combined signal. 
with mega cisterna magna undergo initial (baseline) and long-term hearing and vestibular evaluation. This would help build knowledge about the condition and provide early warning of a change in the status of their hearing or vestibular function.

The subject in the current case study had been exposed to loud noise which affected frequencies between 3000 and $6000 \mathrm{~Hz}$ bilaterally. The subject had not worn ear protection when working in noisy environments, so damage to his hearing (noise-induced hearing loss, the most common preventable cause of hearing loss) may have been due to this exposure. Without doubt, continual noise exposure produces cochlear trauma that can lead to hearing loss and tinnitus. Noise-induced hearing loss usually occurs as a notch at $4000 \mathrm{~Hz}$, spreading to the neighboring frequencies of 3000 and $6000 \mathrm{~Hz}$ [16]. According to the National Institute on Deafness and Other Communication Disorders, tinnitus is the first sign of hearing loss in the elderly [17].

Since the subject was 54 years old, the age factor could have contributed to his hearing loss due to changes in the inner ear and nerve pathways from the ear to the brain. Age-related hearing loss (or presbycusis) is characterized by decreased hearing sensitivity, impaired sound localization, and poorer ability to understand speech, particularly in noisy environments [18]. Furthermore, certain medical conditions (e.g., high blood pressure) and medications (e.g., chemotherapy drugs) can also play a role in hearing loss.

Due to the progressive change in his hearing, the subject was recommended to use amplification. Hearing aids compensate for hearing loss and can also help with tinnitus in some cases. Because hearing aids amplify sounds and produce better hearing, the focus on tinnitus appears to decrease [17]. Bimodal hearing (i.e., using two different types of hearing loss solution, one in each ear) was one available option. The subject could have used a hearing aid in the left ear and a cochlear implant (CI) in the right, since the hearing in the left ear was not severe enough to warrant a CI. Yoon et al. (2015) reported that bimodal hearing increased speech understanding in noise by $12 \%$ compared to just a single CI. CIs also help to mask tinnitus [19].

However, BiCROS amplification was the most suitable option for the subject. He was fitted with BiCROS because both ears had hearing loss and one ear could hear substantially better than the other. The fitting can be determined using both objective and subjective methods. Hays (2006) reported three techniques for fitting CROS or BiCROS devices: (a) using probe microphone acoustic measures; (b) a functional test of speech and/or speech in noise; and (c) the use of questionnaires [e.g., Client Oriented
Scale of Improvement (COSI) and the Abbreviated Profile of Hearing Aid Benefit (APHAB)] or careful followup [20]. Oeding and Valente (2013) examined the benefit from a BiCROS system using APHAB in which participants completed the questionnaire for unaided listening and then again 4 weeks later after use of the BiCROS system. The results indicated that participants perceived significant benefits from the BiCROS system - across the APHAB domains of ease of communication, reverberation, and background noise [21].

In this case, the rehabilitation process began immediately after the subject was fitted with BiCROS. The process involved post-fitting orientation, counseling, and rehabilitation. The physical fit of BiCROS was checked to make sure it was comfortable, and the devices were programmed and adjusted based on the subject's hearing loss and lifestyle needs. The subject was advised on how to use the system and make adjustments for different hearing environments, how to insert and remove them, and how to change the batteries and clean and care for them properly. Tips and strategies for better communication were discussed, such as avoiding sitting next to loud noises and to make sure to face the speaker during a conversation. The subject had no complaints about his hearing system at the time of fitting. Follow-up visits were scheduled.

\section{Conclusions}

This case report of asymmetrical bilateral SNHL in an older man with mega cisterna magna suggests that the condition may cause hearing and/or vestibular symptoms. When a case of asymmetrical hearing loss is identified, it should become a red flag. Therefore, it is important to know whether this change in physiology has an effect on the audiogram. Audiological tests must be looked at as part of the bigger picture, not simply as individual pieces, and in confirmed mega cisterna magna cases further investigation must be undertaken to find out the cause of hearing loss and possible dizziness. Hearing aids can help patients with mega cisterna magna who suffer from hearing loss, although medical clearance is necessary to fit new hearing aids, particularly if hearing loss is progressive. Further research is needed to determine the audiological and vestibular symptoms of a larger sample of patients with mega cisterna magna.

\section{Acknowledgments}

The author thanks the subject for participation and the anonymous referees for their useful suggestions.

\section{Conflicts of interests}

The author has no conflict of interest to declare.

\section{References}

1. Tao G, Yew DT, Gu T, Liu S, Ma Z, Zhan X, Cheng L, Li C. Sexrelated differences in the anteroposterior diameter of the foetal cisterna magna. Clin Radiol, 2008; 63(9): 1015-8.
2. Ek S, Anadakumar C, Wong YC, Chau TM, Gole LA, Malarvishy G. Enlargement of cisterna magna as an indicator of chromosomal abnormalities in a low-risk Asian population. J Perinat Med, 1998; 26(4): 325-7. 
3. Haimovici JA, Doubilet PM, Benson CB, Frates MC. Clinical significance of isolated enlargement of the cisterna magna $(>10 \mathrm{~mm})$ on prenatal sonography. J Ultrasound Med, 1997; 16(11): 731-4.

4. Pilu G, Falco P, Perola A, et al. Ultrasound evaluation of the fetal neural axis. In: Callen PW, editor. Ultrasonography in $\mathrm{Ob}$ stetrics and Gynecology, 5th ed. Philadelphia, PA: WB Saunders; 2008; p. 363-91.

5. Robinson AJ, Goldstein R. The cisterna magna septa: vestigial remnants of Blake's pouch and a potential new marker for normal development of the rhombencephalon. J Ultrasound Med, 2007; 26(1): 83-5.

6. Steiger RM, Porto M, Lagrew DC, Randall R. Biometry of the fetal cisterna magna: estimates of the ability to detect trisomy 18 . Ultrasound Obstet Gynecol, 1995; 5(6): 383-90.

7. Bosemani T, Orman G, Boltshauser E, Tekes A, Huisman TAGM, Poretti A. Congenital abnormalities of the posterior fossa. Radiographics, 2015; 35: 200-20.

8. Ferentinos PP, Kontaxakis VP, Havaki-Kontaxaki BJ, Paplos KG, Pappa DA, Soldatos CR. Refractory psychosis and prominent cognitive deficits in a patient with mega-cisterna magna. Prog in Neuropsychopharmacol, 2007; 31: 561-3.

9. Yildiz H, Yazici Z, Hakyemez B, Erdogan C, Parlak M. Evaluation of CSF flow patterns of posterior fossa cystic malformations using CSF flow MR imaging. Neuroradiology, 2006; 48(9): 595-605.

10. Zimmer EZ, Lowenstein L, Bronshtein M, Goldsher D, AharonPeretz J. Clinical significance of isolated mega cisterna magna. Arch Gynecol Obstet, 2007; 276(5): 487-90.

11. Long A, Moran P, Robson S. Outcome of fetal cerebral posterior fossa anomalies. Prenat Diagn, 2006; 26(8): 707-10.
12. Kumar S, Sur S, Singh A. Mega cisterna magna associated with recurrent catatonia: a case report. Biol Psychiatry, 2011; 70(4): e19.

13. Taylor B. Contralateral routing of the signal amplification strategies. Semin Hear, 2010, 31(4): 378-92.

14. Heard AJ, Urato AC. The isolated mildly enlarged cisterna magna in the third trimester: much ado about nothing? J Ultrasound Med, 2011; 30(5): 591-3.

15. Yar M, Syed RA, Abou Al-Seoud MM. Mega cisterna magna diagnostic dilemma. Arch Dis Child, 2012; 97(Suppl 2): A302.

16. Rabinowitz PM, Galusha D, Slade MD, Dixon-Ernst C, Sircar $\mathrm{KD}$, Dobie RA. Audiogram notches in noise-exposed workers. Ear Hear, 2006; 27(6): 742-50.

17. National Institute on Deafness and Other Communication Disorders. Tinnitus. 2017; https://www.nidcd.nih.gov/health/tinnitus $\# 6$ [accessed 25 November 2018].

18. Gates GA, Mills JH. Presbycusis. Lancet, 2005; 366: 1111-20.

19. Yoon YS, Shin Y, Gho JS, Fu QJ. Bimodal benefit depends on the performance difference between a cochlear implant and a hearing aid. Cochlear Implants Int, 2015; 16(3): 159-67.

20. Hayes D. A practice guide to CROS and BiCROS. Audiol Online 2006; https://www.audiologyonline.com/articles/practical-guideto-cros-bicros-977 [accessed 9 January 2019].

21. Oeding K, Valente, M. Sentence recognition in noise and perceived benefit of noise reduction on the receiver and transmitter sides of a BICROS hearing aid. J Am Acad Audiol, 2013; 24(10): 980-91. 